\title{
Profil Kemampuan Kognitif Siswa MAN pada Materi Membiasakan Akhlak Terpuji
}

\author{
Farrah Camelia \\ Fakultas Ilmu Tarbiyah dan Keguruan, UIN Sunan Kalijaga \\ Email: farrahcamelia@gmail.com
}

\begin{abstract}
Abstrak
Penelitian ini bertujuan untuk mengetahui profil kemampuan kognitif siswa MAN pada pelajaran Pendidikan Agama Islam (PAI) materi membiasakan akhlak terpuji. Metode penelitian menggunakan deskriptif kuantitatif. Subyek penelitian sebanyak 40 siswa kelas XI dari MAN 3 Sleman. Instrumen penelitian menggunakan soal pilihan ganda dengan empat option untuk mengukur kemampuan kognitif level C1-C3 dan soal uraian untuk mengukur kemampuan kognitif level C4. Analisis data menggunakan teknik analisis deskriptif berdasarkan persentase kemampuan kognitif siswa. Hasil penelitian menunjukkan bahwa persentase kemampuan kognitif siswa pada kategori sangat tinggi sebesar 52,5\%, kategori tinggi sebesar 40\%, dan kategori sedang sebesar 7,5\%. Kemampuan kognitif siswa berupa kemampuan mengingat (C1) sebesar 95\%, kemampuan memahami (C2) sebesar 82,5\%, kemampuan mengaplikasikan (C3) sebesar 10\%, dan kemampuan menganalisis (C4) sebesar 40\%. Kemampuan kognitif level C3 dan C4 masih sangat rendah dan membutuhkan bimbingan serta inovasi dalam pembelajaran. Pelatihan berpikir kritis perlu diterapkan agar kemampuan kognitif siswa mengalami peningkatan. Peningkatan kemampuan kognitif tersebut diharapkan dapat membantu siswa dalam mengambil keputusan dan menentukan sikap di kehidupannya.
\end{abstract}

\section{Kata Kunci: Kemampuan kognitif, Membiasakan akhlak terpuji}




\begin{abstract}
This study aims to determine the profile of the cognitive abilities of MAN students in the subject of Islamic Religious Education (PAI) on the material of familiarize commendable morals. The research method used descriptive quantitative. The research subjects were 40 students of class XI MAN 3 Sleman. The research instrument used multiple choice questions with four options to measure cognitive abilities at $\mathrm{C} 1-\mathrm{C} 3$ levels and essay questions to measure cognitive abilities at $\mathrm{C} 4$ levels. Data analysis used descriptive analysis techniques based on the percentage of students' cognitive abilities. The results showed that the percentage of students' cognitive abilities included in the very high category was $52.5 \%$, the high category was $40 \%$, and the medium category was $7.5 \%$. The students' cognitive abilities in the form of the ability to remember (C1) by $95 \%$, the ability to understand (C2) by $82.5 \%$, the ability to apply $(\mathrm{C} 3)$ by $10 \%$, and the ability to analyze (C4) by $40 \%$. the value of cognitive ability levels $\mathrm{C} 3$ and $\mathrm{C} 4$ is very low and requires guidance and innovation in learning. Critical thinking training should be applied to improve students' cognitive abilities. Thus, it is expected to help students in making decisions and determining attitudes in their lives.
\end{abstract}

\title{
Keywords: Cognitive abilities, Commendable morals
}

\section{Pendahuluan}

Beberapa tahun terakhir, perkembangan teknologi semakin canggih. Setiap individu dengan mudah mengakses internet dan media sosial. Jumlah pengguna internet di Indonesia pada 2021 mencapai 202,6 juta jiwa, penggunanya berusia 16 sampai 64 tahun (Riyanto, 2021). Aktivitas berinternet yang saat ini digemari yaitu bermedia sosial, rata-rata mereka menggunakan waktu sekitar 3 jam setiap harinya di platform jejaring sosial. Oleh karena itu tidak dapat dipungkiri bahwa media sosial memiliki pengaruh besar dalam kehidupan seseorang.

Para remaja dengan mudah mengakses media sosial seperti Twitter, Instagram, dan TikTok yang saat ini sedang digemari oleh banyak kalangan. Selain memiliki dampak positif, media sosial juga memiliki dampak negatif di antaranya mengganggu kegiatan belajar, bahaya kejahatan, dan penipuan (Secsio, 2016). Berita yang beberapa 
bulan terakhir menggemparkan dunia pendidikan, 5 siswi SMP mengunggah video di TikTok sedang menginjak-injak rapor (Rachmawati, 2020), perilaku buruk seorang siswa yang merokok di dalam kelas dan menantang gurunya hingga pakar Hukum dan Tata Negara bapak Mahfud MD turut berkomentar "keterlaluan" setelah menyaksikan video yang viral di media sosial itu (Tribunnews.com, 2019). Lalu kejadian mengenaskan seorang remaja tewas karena nekat menghentikan truk yang sedang melintas demi mengikuti konten yang sedang viral di TikTok. Menurut seorang psikolog asal Solo, salah satu penyebab remaja melakukan hal itu ialah pengaruh pertemanan di lingkungan dan pembentukan saraf otak yang belum sempurna sehingga remaja tidak memikirkan risiko dari perbuatannya tersebut (Putri, 2021).

Salah satu upaya yang dapat dilakukan untuk pembinaan remaja di antaranya perbaikan akidah, keluarga dan pendidikan (Ahmadi, 2017). Pendidikan melalui pembelajaran Pendidikan Agama Islam (PAI) mengharapkan siswa bertambah wawasan pengetahuan dengan peningkatan kecakapan, keterampilan, berkarakter mulia, dan berbudi pekerti luhur. Membahas mengenai karakter dan budi pekerti, mata pelajaran akidah akhlak sudah seharusnya menjadi salah satu perantara peserta didik menjadi insan yang berkarakter mulia dan berakhlak terpuji, khususnya materi membiasakan akhlak terpuji.

Beberapa bentuk akhlak terpuji yang terdapat dalam materi ini yaitu akhlak berpakaian, akhlak berhias, akhlak perjalanan, akhlak bertamu dan akhlak menerima tamu (Kementerian Agama RI, 2015). Untuk mengetahui tercapainya pembelajaran, maka diperlukan pengujian kompetensi peserta didik. Kompetensi peserta didik dalam materi akidah akhlak ditinjau dari aspek kognitif seharusnya meningkat pada setiap akhir pembelajaran, karena kemampuan kognitif akan membentuk intelektual peserta didik dan kepribadian peserta didik.

Terkait tindakan remaja yang labil dan tidak berpikir panjang mengenai risiko perbuatannya, berhubungan dengan level kemampuan berpikir remaja itu sendiri. Kognitif atau pengetahuan merupakan salah satu kompetensi yang wajib dicapai dalam pembelajaran. Ranah kognitif merupakan ranah yang melingkupi kegiatan mental begitu juga hasil belajar ranah ini ialah segala usaha yang berhubungan dengan aktivitas otak. Untuk mengetahui tercapainya tujuan atau objek pembelajaran pada ranah kognitif, Benyamin S. Bloom bersama 
rekannya mengembangkan sebuah metode pengelompokan tujuan pendidikan yang disebut dengan taksonomi, terdiri dari mengingat (C1), memahami (C2), mengaplikasikan (C3), menganalisis (C4), mengevaluasi (C5), dan mengkreasi (C6) (Sahlan, 2015).

Taksonomi Bloom telah menjadi sebuah pemikiran yang menjadi pengaruh dalam bidang pendidikan (Darmawan, 2013). Tercapainya kemampuan mengingat, memahami, mengaplikasikan, dan menganalisis diharapkan dapat memberi dampak positif kepada remaja dalam kegiatan sehari-hari khususnya membiasakan akhlak terpuji. Berdasarkan uraian tersebut, maka perlu adanya analisis profil kemampuan kognitif siswa pada materi membiasakan akhlak terpuji.

\section{Metode}

Metode yang digunakan untuk mengetahui profil kemampuan kognitif siswa dalam penelitian ini yaitu deskriptif kuantitatif. Subyek penelitian sebanyak 40 siswa kelas XI Tahun Akademik 2020/2021 dari Madrasah Aliyah Negeri (MAN) 3 Sleman Yogyakarta. Data diperoleh dari instrumen penelitian yang menggunakan soal pilihan ganda dengan empat option untuk mengukur kemampuan kognitif pada ranah $\mathrm{C} 1-\mathrm{C} 3$, jumlah soal sebanyak 6 butir dan 3 soal uraian untuk mengukur kemampuan analisis atau $\mathrm{C} 4$.

Data yang telah terkumpul kemudian diolah dan dianalisis menggunakan teknik analisis deskriptif berdasarkan persentase siswa yang menjawab benar dan salah dari tes kemampuan kognitif yang diberikan. Teknik penskoran menggunakan pembobotan soal bentuk campuran, bobot nilai soal pilihan ganda $80 \%$ dan soal uraian $20 \%$. Rumus penghitungan skor:

\section{$\frac{\text { Jumlah soal yang dijawab benar }}{\text { Jumlah soal }} X$ bobot nilai}

Hasil perhitungan yang diperoleh dikelompokkan berdasarkan kategori pada Tabel 1.

Tabel 1. Tafsiran Kemampuan Kognitif (Junaidi, 2017)

Kategori

Sangat tinggi

Tinggi

Rata-rata (sedang)

Rendah

Sangat rendah
Persentase (\%) $80 \%<\mathrm{P} \leq 100 \%$ $60 \%<\mathrm{P} \leq 80 \%$ $40 \%<\mathrm{P} \leq 60 \%$ $20 \%<\mathrm{P} \leq 40 \%$ $0 \%<\mathrm{P} \leq 20 \%$ 


\section{Hasil Penelitian}

Berikut hasil kemampuan kognitif siswa pada materi membiasakan akhlak terpuji disajikan pada Tabel 2.

Tabel 2. Hasil Kemampuan Kognitif Siswa

\begin{tabular}{|c|c|c|c|}
\hline No & Nama & Skor & Kategori \\
\hline 1 & As & 86,6 & Sangat tinggi \\
\hline 2 & Nsm & 80,6 & Sangat tinggi \\
\hline 3 & Nuae & 69,3 & Tinggi \\
\hline 4 & $\mathrm{Sa}$ & 96 & Sangat tinggi \\
\hline 5 & Fnr & 69,3 & Tinggi \\
\hline 6 & Zda & 86,6 & Sangat tinggi \\
\hline 7 & Dan & 96 & Sangat tinggi \\
\hline 8 & Anu & 80,6 & Sangat tinggi \\
\hline 9 & Sftp & 82,6 & Sangat tinggi \\
\hline 10 & Mnh & 84,6 & Sangat tinggi \\
\hline 11 & Ass & 82,6 & Sangat tinggi \\
\hline 12 & $\mathrm{Fa}$ & 74,6 & Tinggi \\
\hline 13 & Zs & 65,3 & Tinggi \\
\hline 14 & $\mathrm{Iz}$ & 86,6 & Sangat tinggi \\
\hline 15 & $\mathrm{Nmz}$ & 86,6 & Sangat tinggi \\
\hline 16 & Aya & 98 & Sangat tinggi \\
\hline 17 & Lna & 80,6 & Sangat tinggi \\
\hline 18 & Nnf & 86,6 & Sangat tinggi \\
\hline 19 & Am & 67,3 & Tinggi \\
\hline 20 & Mgh & 69,3 & Tinggi \\
\hline 21 & $\mathrm{Nrs}$ & 86,6 & Sangat tinggi \\
\hline 22 & Idn & 74,6 & Tinggi \\
\hline 23 & Mfs & 59,3 & Sedang \\
\hline 24 & Nnm & 46 & Sedang \\
\hline 25 & Sfn & 86,6 & Sangat tinggi \\
\hline 26 & Ehs & 78,6 & Tinggi \\
\hline 27 & Nts & 78,6 & Tinggi \\
\hline 28 & Snhn & 86,6 & Sangat tinggi \\
\hline 29 & Frf & 98 & Sangat tinggi \\
\hline 30 & $\mathrm{Rw}$ & 69,3 & Tinggi \\
\hline 31 & Ahz & 86,6 & Sangat tinggi \\
\hline 32 & $\mathrm{Nh}$ & 86,6 & Sangat tinggi \\
\hline 33 & Rzrpa & 71,3 & Tinggi \\
\hline 34 & Es & 78,6 & Tinggi \\
\hline
\end{tabular}




$\begin{array}{cccc}35 & \text { Ar } & 74,6 & \text { Tinggi } \\ 36 & \text { Faaa } & 78,8 & \text { Tinggi } \\ 37 & \mathrm{Ra} & 46 & \text { Sedang } \\ 38 & \mathrm{Mr} & 61,3 & \text { Tinggi } \\ 39 & \mathrm{Hnm} & 80,6 & \text { Sangat tinggi } \\ 40 & \mathrm{Dd} & 65,3 & \text { Tinggi }\end{array}$

Berdasarkan Tabel 2 kemampuan kognitif siswa kelas XI MAN pada materi pembiasaan akhlak terpuji dengan kategori sangat tinggi sebanyak 21 orang atau 52,5\%, kategori tinggi sebanyak 16 orang atau $40 \%$, dan kategori sedang sebanyak 3 orang atau 7,5\%. Secara rinci dapat disajikan pada Grafik 1.

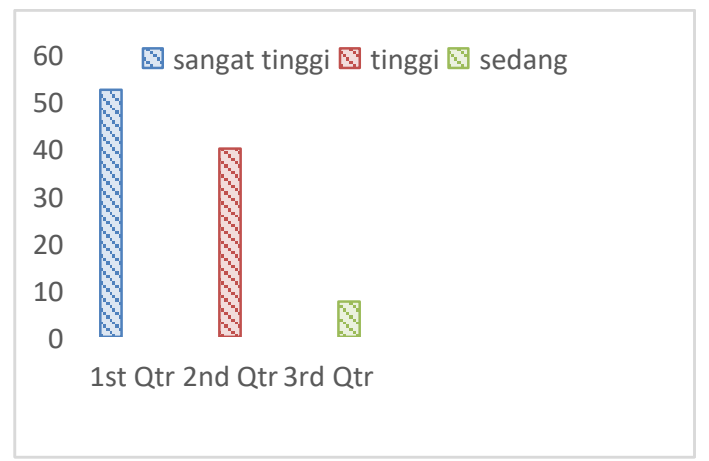

Grafik 1. Persentase Kemampuan Kognitif Siswa

\section{Pembahasan}

Aspek kemampuan kognitif siswa yang diteliti dirincikan sebagai berikut:

\section{Kemampuan Mengingat}

Kemampuan mengingat menurut Anderson dalam (Wiyoko, 2020) merupakan proses mental kognitif di dalam mengambil pengetahuan yang dibutuhkan dari memori jangka panjang. Oleh karena itu mengingat berada pada level paling rendah dalam ranah domain kognitif karena siswa tidak dituntut memahami atas materi yang dihafal (Sutrisno, 2019). Agar "mengingat" dapat menjadi bagian belajar bermakna, alangkah baiknya tugas menghafal dihubungkan dengan ranah pengetahuan yang lebih luas.

Meski kemampuan mengingat berada pada level dasar, kemampuan ini merupakan dimensi yang berperan penting dalam 
proses pembelajaran yang bermakna (meaningfull learning) dan pemecahan masalah (problem solving). Kemampuan ini dimanfaatkan untuk menyelesaikan berbagai masalah yang jauh lebih kompleks (Gunawan, 2012).

Hasil analisis menunjukkan bahwa siswa MAN memiliki tingkat kemampuan mengingat sebesar 95\% dengan kategori sangat tinggi untuk materi membiasakan akhlak terpuji. Salah satu penyebab mengapa siswa mudah mengingat materi ini, karena contoh pembahasan mengenai akhlak terpuji selalu ada dalam materi akidah akhlak sejak pendidikan dasar.

\section{Kemampuan Memahami}

Pemahaman merupakan kemampuan untuk menangkap makna dan arti dari bahan yang dipelajari (Sahlan, 2015). Kemampuan tersebut digunakan untuk menguraikan esensi dari sebuah bacaan, mengubah data yang disajikan dalam bentuk tertentu ke dalam bentuk lain. Saat peserta didik mulai mengerti suatu materi, maka pada waktu mendatang materi tersebut dapat dimanfaatkan untuk memecahkan masalah dan membuat keputusan. Oleh karena itu, mengerti pada level ini sifatnya berupaya menentukan apakah siswa memahami informasi secara bermakna.

Hasil analisis menunjukkan bahwa siswa MAN memiliki tingkat kemampuan memahami sebesar $82,5 \%$ dengan kategori tinggi pada materi membiasakan akhlak terpuji. Kemampuan siswa dalam memahami konsep dari materi ini dilihat dari hasil pengerjaan soal yang diberikan. Soal pilihan ganda sebanyak 2 soal yaitu soal no 3 dan 4 dengan indikator ketercapaian memahami etika bertamu dan fungsi pakaian.

\section{Kemampuan Mengaplikasikan}

Kemampuan mengaplikasikan yaitu penggunaan suatu prosedur untuk menyelesaikan masalah. Peserta didik menggunakan materi yang dipelajari pada situasi baru (Sahlan, 2015). Contohnya mengaplikasikan suatu dalil, konsep, metode, dan teori untuk memecahkan masalah. Kemampuan mengaplikasikan berada di nomor 5 dan 6 dengan indikator ketercapaian menjelaskan esensi dalil etika berhias dan konsep bertamu. Hasil analisis kemampuan siswa dalam mengerjakan soal yang mengukur kemampuan mengaplikasikan sebesar 10\% dengan kategori sangat rendah.

Salah satu metode pembelajaran yang dapat digunakan untuk meningkatkan kemampuan mengaplikasikan yaitu cooperative 
learning. Pembelajaran kooperatif memberi kesempatan kepada siswa untuk menyelesaikan tugas terstruktur. Oleh karena itu seyogyanya kelompok beranggotakan siswa dengan tingkat kemampuan yang berbeda-beda, siswa dapat bekerja sama dan saling membantu untuk memahami pelajaran (Suyadi, 2013).

\section{Kemampuan Menganalisis}

Kemampuan mendeskripsikan atau menguraikan suatu materi menjadi beberapa komponen sehingga susunannya dapat dimengerti. Hasil analisis data yang diperoleh menunjukkan bahwa siswa MAN memiliki kemampuan menganalisis sebesar 30\% dengan kategori rendah. 3 butir soal yang digunakan untuk mengukur kemampuan menganalisis diterapkan pada indikator menjelaskan sebab Islam mengedepankan akhlak, kemudian pandangan siswa mengenai jilbab untuk anak perempuan, dan akhlak bepergian saat pandemi Covid 19.

Hasil analisis tentang kemampuan menganalisis tergolong rendah. Heong menjelaskan siswa mengalami kebuntuan ide dalam memecahkan permasalahan yang diberikan (Heong, 2011). Selain itu tidak adanya pembiasaan yang melatih untuk mengembangkan kemampuan kognitif juga menjadi salah satu penyebab rendahnya kemampuan analisis siswa (Nurazizah, Sinaga \& Jauhari, 2017).

Sejauh yang peneliti amati dalam buku mata pelajaran akidah akhlak pada halaman awal sebelum pengkajian materi, siswa hanya diminta untuk mengamati, kemudian di akhir materi siswa diajak untuk berdiskusi perkelompok. Perlu adanya inisiatif pendidik untuk melatih kemampuan analisis siswa, bisa dengan penyelesaian masalah yang kontekstual dengan konsep HOTS (Higher Order Thinking Skill) atau aktif mengajak siswa berdiskusi dan meningkatkan rasa ingin tahu siswa. Terdapat berbagai macam metode pembelajaran kurikulum 2013 untuk meningkatkan kemampuan analisis di antaranya metode Problem Based Learning (PBL), Brain-based Learning (BbL), mind mapping, dan konsep Higher Order Thinking Skill (HOTS).

\section{Kesimpulan dan Implikasi}

Berdasarkan hasil analisis profil kemampuan kognitif siswa dari C1 hingga $\mathrm{C} 4$ menunjukkan bahwa kemampuan mengaplikasikan (C3) dan menganalisis (C4) masih tergolong rendah. Sedangkan tantangan yang dihadapi siswa pada masa kini jauh lebih besar, sehingga pendidik harus terus melakukan inovasi dalam mengajar, 
tidak bisa hanya berpatokan pada buku paket saja. Pelatihan berpikir kritis juga perlu diterapkan agar kemampuan kognitif siswa mengalami peningkatan. Peningkatan kemampuan kognitif tersebut diharapkan dapat membantu siswa dalam mengambil keputusan dan menentukan sikap di kehidupannya.

Saran yang dapat diberikan ialah sebagai berikut: Pertama, Kepada guru mata pelajaran akidah akhlak agar membimbing jalannya diskusi di kelas, menyajikan problem kontekstual yang dapat memicu pertanyaan dan jawaban dari siswa. Guru juga dapat menggunakan berbagai strategi pembelajaran $\mathrm{K} 13$, salah satunya cooperative learning dan Problem Based Learning (PBL), Brain-based Learning (BbL), mind mapping, dan konsep Higher Order Thinking Skill (HOTS) untuk meningkatkan kemampuan kognitif siswa. Kedua, Kepada siswa kelas XI MAN 3 Sleman hendaknya berperan aktif dalam pembelajaran dan memiliki rasa ingin tahu yang tinggi terhadap materi yang dipelajari.

\section{Daftar Pustaka}

Ahmadi, A. (2017). Peran Pendidikan Agama Islam Dalam Membina Para Remaja. Uin Sultan Maulana Hasanudin Banten.

Galuh Putri Riyanto. (2021). Jumlah Pengguna Internet 2021 tembus 202 Juta.

https://tekno.kompas.com/read/2021/02/23/16100057/jumlahpengguna-internet-indonesia-2021-tembus-202-

juta\#: :text=KOMPAS.com - Pengguna internet di,dibandingkan pada Januari 2020 lalu.

Gloria Stevani Putri. (2021). Viral Remaja Nekat hentikan Truk, Ini Penyebabnya Kata Psikolog. https://www.kompas.com/sains/read/2021/04/07/180000823/viral -remaja-nekat-hentikan-truk-ini-penyebabnya-katapsikolog?page=all\#

Gunawan, I. (2012). Taksonomi Bloom - revisi Ranah Kognitif: Kerangka Landasan Untuk Pembelajaran, Pengajaran dan Penilaian. Premiere educandum: jurnal, 2(2), 105.

Heong, Y.M., Othman, W.B., Yunos, J.M., K., \& T.T., Hassan, R.B. \& Mohamad, M. M. B. (2011). The Level of Marzano Higher Order Thinking Skills among Technical Education Students. International Journal of Social Science and Humanity, 1(2), 121- 
125.

I Putu Ayub Darmawan. (2013). Revisi Taksonomi Pembelajaran Benyamin S. Bloom. Satya Widya, 29(1), 39.

Junaidi. (2017). Analisis Kemampuan Berpikir Kritis Matematika

Siswa dengan Menggunakan Graded Response Models di SMA Negeri 1 Sakti. 4(1), 20.

Kementerian Agama RI. (2015). Buku Siswa Akidah Akhlak Madrasah Aliyah Kelas XI.

Nurazizah, S., Sinaga, P., \& Jauhari, A. (2017). Profil Kemampuan Kognitif dan Keterampilan Berpikir Kritis Siswa SMA pada Materi Usaha dan Energi. Penelitian \& Pengembangan Pendidikan Fisika, 3(2), 197-202.

Rachmawati, F. (2020). Kisah 5 Siswi SMP Injak Rapor di TikTok, Tak Hargai Guru, Dikeluarkan.

Sahlan, M. (2015). Evaluasi Pembelajaran. STAIN Jember Press.

Sutrisno, S. (2019). Desain Kurikulum Perguruan Tinggi. Remaja Rosdakarya.

Suyadi. (2013). Strategi Pembelajaran Pendidikan Karakter. Remaja Rosdakarya.

Tribunnews.com. (2019). Komentar Mahfud MD Soal Ulah Siswa SMP di Gresik Merokok di Kelas dan Tantang Gurunya: Keterlaluan.

Wilga Secsio Ratsja Putri, R. Nunung Nurwati, \& M. B. S. (2016). Pengaruh Media Sosial Terhadap Perilaku Remaja. PROSIDING KS: RISET \& PKM, 3(1), 51.

Wiyoko, T. dan A. (2020). Analisis Profil Kemampuan Kognitif Mahasiswa PGSD Pada Mata Kuliah Ilmu Alamiah Dasar. IJIS Edu : Indonesian J. Integr. Sci. Education, 2(1), 31. 